\title{
The Effect of Corporate Social Responsibility on Job Satisfaction (Empirical Study on Jordanian Private Hospital)
}

\author{
Dr Waiel Alkayed \\ Department of Management, the World Islamic Sciences \& Education University- Jordan
}

\begin{abstract}
Corporate social responsibility has a positive effect with businesses job satisfaction especially with services introduce by the organization toward employees. The growing attention to Corporate Social responsibility is based on its ability to authority corporation performance. CSR movement is distribution over the world and in the existing years a great number of frameworks have been developed, the majority being developed in the West. The current study intense on the effecting of Corporate Social responsibility job satisfaction in Jordanian private hospital
\end{abstract}

Methodology A questionnaire was distributed to 100 employees in Al Jordanian private hospitals in Amman City, over a month in 2016, with results from Likert scales analyzed using descriptive analysis, means and SDs to tabulate and analyzed.

Results: Analysis of 84 suitable responses among private hospitals employees found a significant effect CSR on job satisfaction at the two Hypotheses.

Recommendations: Get better employees overall working environment and promotion for employees which is based on job satisfaction.

Keywords: Corporate Social Responsibility job satisfaction, private hospital, Jordan

\section{Introduction}

Most hospitals in Jordan are concentrated in Amman, and many boast of international accreditation. Some of the popular hospitals situated in Jordan include the King Hussein Cancer Center, which also happens to be one of the top cancer treatment centers in the world. More information can be obtained on the King Hussein Cancer Center web page.

Another notable establishment is the Specialty Hospital, located in Amman, which has been successfully serving patients since 1993. International accreditation apart, Specialty Hospital also provides the best in terms of technology and expertise.

Jordan Hospital is another JCI accredited hospital, complete with a highly trained and experienced staff. Providing multispecialty care, Jordan Hospital also provides extremely attractive rates, which are approved by the government as well as the Jordan Medical Association.More information can be obtained on the Jordan Hospital web page.

With the Jordanian government going the extra mile for facilitating foreigners to receive medical treatment fast and securely, Jordan is the ideal choice for medical treatment abroad.

Jordan has several hospitals with international accreditations such as Joint Commission International, as well as the required ISO certification. Also a number of these hospitals are staffed by doctors who are America board certified; increasing the level of expertise and experience they have to offer.

Apart from international accreditations, numerous Jordanian hospitals are also recipients of HCAC, which stands for Health Care Accreditation Council, accreditation. The HCAC is Jordanâ $€^{\mathrm{TM}_{\mathrm{S}}}$ domestic accreditation system, which has been monitoring and improving health care in Jordan since 2007. HCAC is accredited by ISQua itself, which is recognized as a high level accreditation of quality even by the American Medical Association. (www.medicaltourismco.com/hospitals-in-jordan)

In today business notion of corporate social responsibility imply that organization enthusiastically incorporate social concern in their operations with their Employees as a primary part of stakeholder The concept of Corporate Social Responsibility is one of ethical issues contiguous corporate decision making and performance, therefore if a firm ought to undertake confident activities or from doing so because they are helpful or hurtful to society is a important question. Social issues toward the employees value ethical fear of their own and should lead managers to think the social impacts of corporate activities in decision making.

\section{Literature Review}

\subsection{CSR employees}

The the same opportunity for rewards and development have to to be provided to every employee for association to be socially responsible. Responsible employment practice with well-trained, and motivated employees, who are adequately rewarded - sharing in the collection successes ought to be instituted. The group that ignores this responsibility may possible face a threat of losing productive, highly motivated employees, Alafi, Al-Qeed and Alkayed ,2014) indicate factors affect employee job satisfaction. And They set up that the overall employee 
dissatisfaction was $88.4 \%$ (satisfaction $11.6 \%$ ) with the highest item score for "Hospital's precious on normal of living raising of Jordanian" and lowest for "priorities reporting system and the present study inconsistent with Alafi etal...2014, but Choi and Yanni Yu,(2014) exposed in a research conduct in China to investigate the effect of CSR practice on employees ${ }^{\text {ee }}$ attitudes and behaviors. The authors examine the interference impact of employees The outcome showed that employees ${ }^{\text {ee }}$ perceptions of CSR practices have a positive effect on their managerial commitment and managerial citizenship behavior. The administrative commitment ultimately mediates the relationship only through managerial citizenship behavior, while administrative citizenship behavior partially mediates the relationship between CSR practices and organizational performance, and the current study reliable with the Yanni Yu,(2014) result

For employee job satisfaction in the workplace and its promotion, some scholars analyze this factor. Both employee accomplishment and dissatisfaction are precious by the job environment and promotion ( Alafi et al 2014) how much job accomplishment is possible within it (Hussami, 2008). supposed justice like just as opportunities in terms of Promotion is a key factor affecting employee accomplishment and enhanced job satisfaction (Parvin \& Kabir, 2011). (Sharon, L. C. et. al., 2012). Job accomplishment is a complex issue immediate different facet (Alafi et al., 2014) and focus to factors like wages, (Lane, Esser, Holte \& McCusker, 2010). As a result, the achievement of an collection can be significantly strong-minded and affected, together with performance and profit. The significance of research of employee is significant for human relations and management concerning both practitioner in companies and for the scholars seeking and analyzing relationships as well as directors and shareholders As well impacts positively on both the perception of job

\subsection{CSR and job satisfaction}

Big business insiders, like managers look for over provide in corporate social responsibility for their secret benefits in order to develop their standing as high-quality global citizens. There is a significant analyzed relationship between corporate social responsibility behavior and job satisfaction for the period of 1999 to 2007 on 850 US companies. (Blazovich and Smith 2010) explained the relationship between corporate citizenship and job satisfaction. They also examine whether moral corporate behavior was associated with a market-value best. The dissimilar results point to a important relationship between corporate behavior and job satisfaction As a result of Study conducted by (Joshi et al.,2010) there is strongly relationship between income Making and Social Responsibility . income making is the necessary reason for an venture to extend and grow while social responsibility is the necessary duty of the "state" that must center upon the background of its stakeholders with social justice. Showed the effect of corporate social responsibility and the friendship standing on its brand fairness in business-to-business markets from the employees awareness on a sample of industrial purchasers in Taiwan's.

\section{Objective of Study}

Supplementary information about CSR and job satisfaction will create a high-quality contributions to the body of the Literature . as a consequence the present study aim to find out and identify strategies that affect the relationship between CSR activities on employees job satisfaction In business in general and in Jordanian private hospital

\section{Research Model}

\begin{tabular}{|l|}
\hline CSR factors \\
\\
\hline Prmotion \\
\end{tabular}

Job satisfaction

\section{CSR Defined}

The present research defined the CSR as an behavior from the business toward employees where the business function and help them with diverse factors like promotion working environment.

\section{Job satisfaction}

The present research define the job satisfaction as accomplishment of employees in result its carry out of corporate social responsibility toward employees promotion, employees working place 


\section{Hypothesis}

H.1 There is a positive effect of CSR in terms of promotion and job satisfaction in Jordanian private hospital.

H.2 There is a positive effect of CSR in terms of working environment and job satisfaction in Jordanian private hospital.

\section{Methodology}

The population of the present study covers the Jordanian private hospital employees. It is an significant indication that Jordan became A number one for medicine tourism in the middle east and north Africa countries . Now Jordanian private hospital play a significant role in Jordan national economic and it should be do A CSR services toward the employees to improve their quality of life in result lead to high Group performance . The sampling method used to collect the data is random sampling in order to avoid bias with the opinions. Samples were randomly drawn from the different level of the employees in different Group of the hospitals. 100 questionnaires were distributed to the employees 91 was return, and the researcher found 84 valid for analysis.

\subsection{Development of questionnaires}

The questionnaires were intended to measure variables to find the effect of the CSR and job satisfaction. All questions are based on two hypotheses generated for the present research. The questions were intended in such a way that the member were able to understand and answer the questions. The model of questionnaire for CSR was modified from Alafi (2014)as it was referring to the two variables which affected on job satisfaction. The first independent variable contains substance apply to the employees promotion. The second independent variable, working environment, The dependent Variables measured.

Participants were asked to point to their awareness on job satisfaction. A five -point Likert scale ranging from strongly disagree (1) to strongly agree (5) was used

\section{Results:}

Table (1): Descriptive statistics of Employees promotion

\begin{tabular}{|l||l||l||l||}
\hline No & Item & Mean & $\begin{array}{l}\text { Standard } \\
\text { deviation }\end{array}$ \\
\hline \hline Promotion & $\begin{array}{l}\text { The Group management provide equal opportunities to its employees in term } \\
\text { of promotion }\end{array}$ & 2.94 & 0.6519 \\
\hline \hline 2 & $\begin{array}{l}\text { The Group management in the biased with some of my colleagues in terms of } \\
\text { promotion }\end{array}$ & 3.53 & 0.8534 \\
\hline \hline 3 & $\begin{array}{l}\text { The Group management is constantly preparing promotion programs for its } \\
\text { employees }\end{array}$ & 3.71 & 0.92671 \\
\hline \hline 4 & $\begin{array}{l}\text { The Group management meets the needs of its employees continuously } \\
\text { promotion }\end{array}$ & 2.45 & 0.76332 \\
\hline \hline Average & 3.3 & 06049 \\
\hline
\end{tabular}

From the Table (1) the means range was (2.45-3.71), the highest means was for the item "the hospital management is constantly preparing promotion programs for its employees with a mean 3.71 and STD of (0.92871) while the lowest The hospital management meets the needs of its employees continuously promotion" with a mean of (2.45), and STD of (0.76532) overall mean was (3.3) with STD of (06049)

Table (2): Descriptive statistics of working environment

\begin{tabular}{|l|l||l||l||}
\hline No & Item & Mean & $\begin{array}{l}\text { Standard } \\
\text { deviation }\end{array}$ \\
\hline \hline Working environment & $\begin{array}{l}2 . \\
85\end{array}$ & 0.8875 \\
\hline \hline 5. & The working environment compared to the work that I do is satisfying. & 3.76 & 0.9712 \\
\hline \hline 6. & $\begin{array}{l}\text { The working environment encourages me to improve the level of quality of } \\
\text { my work. }\end{array}$ & 2.89 & 0.6543 \\
\hline \hline 7. & The working environment that care about hospital . & 3.61 & 0.5643 \\
\hline \hline 8. & The working environment to my hospital. & 3.27 & 0.6765 \\
\hline \hline Average & \\
\hline
\end{tabular}


From the Table (2) the means range was (2.85-3.76), the highest means was for the item "My working environment encourages me to improve the level of quality of my work. with a mean 3.70 and STD of (0.9712) while the lowest Employees that care about hospital object eves rewarded with a mean of (2.80), and STD of (0.6543) overall mean was (3.17) with STD of (0.6765).

Table (3): Descriptive statistics of job satisfaction

\begin{tabular}{|c|c|c|c|}
\hline No & Item & Mean & $\begin{array}{l}\text { Standard } \\
\text { deviation }\end{array}$ \\
\hline \multicolumn{4}{|c|}{ Job satisfaction } \\
\hline 9 & $\begin{array}{l}\text { My hospital has a good reputation } \\
\text { For job satisfaction }\end{array}$ & 4.25 & 0.83540 \\
\hline 10 & $\begin{array}{l}\text { My hospital achieved high return on investment the reason of job } \\
\text { satisfaction }\end{array}$ & 3.25 & 0.74570 \\
\hline 11. & My hospital has a market share more than the competitors & 2.65 & 0.79540 \\
\hline 12 & I feel that I am a strategic partner in My hospital & 3.46 & 0.72341 \\
\hline 13 & My hospital achieved a high annual profit & 3.12 & 0.70811 \\
\hline \multicolumn{2}{|c|}{ Average } & 3.436 & 0.78512 \\
\hline
\end{tabular}

From the Table (3) the means range was (2.65-4.25), the highest means was for the item "My hospital has a good reputation. with a mean 4.25 and STD of (0.83540) while the lowest My hospital has a market share more than the competitors with a mean of (2.65), and STD of (0.79540) overall mean was (3.336) with STD of $(0.78512)$

\section{Correlations}

Table (4)

\begin{tabular}{|c|c|c|}
\hline & & Job satisfaction \\
\hline \multirow[t]{3}{*}{ Promotion } & Pearson Correlation & $.719 * *$ \\
\hline & Sig. (2-tailed) & .000 \\
\hline & $\mathrm{N}$ & 74 \\
\hline \multirow{3}{*}{ Working environment } & Pearson Correlation & $.670 * *$ \\
\hline & Sig. (2-tailed) & .000 \\
\hline & $\mathrm{N}$ & 74 \\
\hline
\end{tabular}

As shown in Table 4 there was a positive and statistically significant relationship between all the independent variables (promotion, working environment CSR ) and the dependent variable (job satisfaction) where it was found that the high effect positive relationship was between promotion CSR and job satisfaction at0.719 and the low effect positive relationship between working environment CSR and (job satisfaction) was 0.670.Based on this, results can be concluded that all the hypotheses were supported. The result proved that all the independent variables promotion, working environment CSR ) have significant positive impact on performance among the Jordanian private hospital.

Table (5)

Regression analysis for relationship between dependent and independent Variables

\begin{tabular}{|l|l|r|r|r|r|r|r|r|}
\hline \multicolumn{1}{|c|}{ Model } & $\mathrm{R}$ & $\begin{array}{r}\mathrm{R} \\
\text { Square }\end{array}$ & $\begin{array}{c}\text { Adjusted R } \\
\text { Square }\end{array}$ & $\begin{array}{c}\text { R Square } \\
\text { Change }\end{array}$ & t-value & Sig. & $\begin{array}{r}\text { Standardized } \\
\text { coefficients b }\end{array}$ & $\begin{array}{c}\text { Durbin- } \\
\text { Watson }\end{array}$ \\
\hline $\begin{array}{l}\text { promotion } \\
\text { CSR }\end{array}$ & $.766 \mathrm{a}$ & .630 & .622 & .041 & 2.933 & 0.000 & .339 & 1.521 \\
\hline $\begin{array}{l}\text { working } \\
\text { CSR }\end{array}$ & $.794 \mathrm{~b}$ & .648 & .637 & .017 & 3.384 & 0.000 & .316 & \\
\hline
\end{tabular}

Above is a multiple regression analysis of the three variables' relationships with Job satisfaction. These variables (promotion CSR and working environment CSR) were retained as predictive of Job satisfaction. The regression model accounted for approximately $64.8 \%(\mathrm{r} 2=0.64 .8)$ of variance in Job satisfaction.. The results of this analysis are shown in Table 5.

\section{Discussion}

Employees promotion was established to have significant influence in Jordanian private hospitales for aspirations for higher salary, which is consistent with findings by Alafi et al., 2014).

These consequences above may propose that management ought to acutely Making and Social Responsibility believe providing their employees with diverse or new types of facilities as in order to provide them more job satisfaction findings indicate that most employees were satisfied with the majority of factors 
tested in the current research: ", employees training which was motivating for employee job satisfaction, this consistent with the prior consequence Parvin and (Kotler, P., and Lee, N. (2005. Also the result of the current research showed a high level of the important effect job satisfaction on CSR which consistent with Study conduct by (Joshi et al.,2010) they establish that there is strongly relationship between Profit.

\section{Limitations of the Study}

Generalization of data to selected Jordanian private hospital employees is not possible also may a bias of the employees considered, especially the data collected from the employees through their work at hospital

\subsection{Future Research}

Opportunities for future research exist in examine other elements affecting employee's job satisfaction.

\subsection{Recommendations}

Establishment of the above analysis of two CSR activated toward the employees on Jordanian private hospital, the outcome suggested the following recommendations to managers on Jordanian private hospital to increase the employees satisfaction

1) get better employees overall payment packages for employees which is based on efficiency rewards

2) ought to the Jordanian private hospital management provide equal opportunities to their employees in term of different type of promotion to get better their ability make them provide a good services.

3) Jordanian private hospital management ought to take into their account the good relationships between the employees in different management levels

\section{References}

Alafi , Al-Qeed and Alkayed ,(2014) Prevalence and Factors Affecting Employee Satisfaction: The Case of King Abdullah University Hospital in Jordan, International Journal of Business and Management; Vol. 8, No. 23; 2013 ISSN 1833-3850 E-ISSN 1833-8119 Published by Canadian Center of Science and Education

Blazovich and Smith, 2010), Social issues in management research: experts" views, analysis and commentary. Business and Society

Choi, Yanni Yu, (2014), The Influence of Perceived Corporate Sustainability Practices on Employees and Organizational Performance-china. Sustainability 2014, 6, 348-364; doi:10.3390/su6010348 ISSN 2071-1050 www.mdpi.com/journal/sustainability

Creasley, K., Bryman, A., Dainty, A., Price, A., Soetanto, R., \& King, N. (2005). Employee perceptions of empowerment. Employee Relation, 27(4), 354-368.

Cyrus IrayaMwangi, 2013 The Relationship between Corporate Social Responsibility Practices and Financial Performance of Firms in the Manufacturing, Construction and Allied Sector of the Nairobi Securities Exchange International Journal of Business, Humanities and Technology

Hussami M. (2008). A Study of nurses' job satisfaction: the relationship to organizational commitment, perceived organizational support, transactional leadership, transformational leadership, and level of education. European Journal of Scientific Research; 22 (2): 286-295.

Joshi et al.,2010) Dissecting the functional specificities of two Hoxproteins Access the most recent version at doi:10.1101/gad.1936910

Genes Dev. 2010 24: 1533-1545

Kotler, P., and Lee, N. (2005). Corporate social responsibility: doing the most good for your company and your cause. Hoboken, New Jersey, Canada

Lane, K. A., Esser, J., Holte, B., \& McCusker, M. A. (2010). A study of nurse faculty job satisfaction in community colleges in Florida. Teaching Learning Nursing, 5, 16-26.

Mustafa, M.H. (2010). International tourism: Number of arrivals in Middle East and Arab World. International Journal of Business and Social Science, 1(1), 37-4

Parvin, M. M., \& Kabir, M. M. N. (2011). Factors affecting employee job satisfaction of the pharmaceutical sector. Australian Journal of Business and Management Research, 1(9), 113-123

Sharon, Lee, (2012), Corporate Social Responsibility in Housing Development - The Developers Perspective. Australia. Journal of Applied Management Accounting Research, 10(2), 5

Selvi et al., (2010), Identification of a novel inhibitor of coactivator-associated arginine methy ltransferase 